\title{
Dental Dysplasia
}

National Cancer Institute

\section{Source}

National Cancer Institute. Dental Dysplasia. NCI Thesaurus. Code C139141.

Chronic degenerative changes of the teeth, mainly the incisors, due to trauma or inflammation. It involves abnormal development of odontogenic tissue and is characterized by abnormal deposits of dentin, cementum, and osteoid. 